\title{
"The Nordic concept" in relation to the arts. Politics and exhibition policy in the Third Reich
}

HANNA PIRINEN*

\begin{abstract}
Nazi Germany used official cultural cooperation for ideological propaganda purposes. Germany did not enter into any distinct cultural agreements with the Nordic countries, but cooperated in separate projects such as art exhibitions. This article focuses on an exhibition of Finnish art organized in Germany in 1935 and on an exhibition of German art correspondingly organized in Finland in 1936. The article discusses the compilation of an exhibition as a statement of opinion. Compiling an exhibition is always a matter of making choices: decisions have to be made on the theme of the exhibition, any larger entity it is to be linked with, what should be included and what should be left out. An exhibition always represents something; it can thus never be non-aligned or 'innocent'. An art exhibition that forms part of cultural cooperation organized by a totalitarian system is an example of an enforced display of ideology.
\end{abstract}

Keywords: Exhibtions, cultural cooperation, cultural policy, Nazi Germany, political art, propaganda.

The rise to power of the National Socialist Party in Germany in 1933 heralded a massive political upheaval which had an impact on all segments of cultural and artistic life as well as everywhere else. Nazi Germany's domestic and foreign policy both involved single-minded politico-cultural propaganda. Propaganda aimed abroad was the responsibility of the efficiently organized cultural administration run by the Foreign Ministry and the Ministry for Public Enlightenment and Propaganda, plus numerous associations subservient to the party together with their various subdivisions.

Nazi Germany entered into cultural agree- ments with Spain and several countries in eastern Europe. As a result, a conscious political programme was created for national cultural exchange, with officials active in running it (Barbian 1992). Germany did not enter into any cultural agreements with the Nordic countries, and there was thus no official basis for widespread cooperation between cultural organizations, university departments or other institutions. Instead, cultural cooperation was channelled into other forms of activity, such as arranging guest appearances, exhibitions and trade fairs in various fields.

This article explores the use of cultural co- 
operation by National Socialist Germany as a means of spreading Nazi propaganda. I shall be focussing on two exhibitions in particular: an exhibition of Finnish art organized in Germany in 1935 and an exhibition of German art correspondingly organized in Finland in the following year. I shall also be touching on an exhibition of Finnish graphic art that toured Germany in 1936. By analysing the exhibition organization, I shall discuss the cooperation between the two countries and the political role of cultural institutions in the public sector. Using the two above exhibitions as case studies, I aim to analyse the political aims that were propounded in official public cultural efforts.

During the period studied, the National Socialist political programme known as the 'Nordic concept' (Nordische Gedanke), which was rooted in race theory but which was expanded into a varied and subtle tool for ideological propaganda in the mid-1930s, had a key role.

The programme was principally the creation of Alfred Rosenberg, the party's main ideologist. This article analyses art exhibitions as a means of implementing the aims of Rosenberg's ideology. My discussion is linked with American analytical historical research. Hayden White has highlighted the emphasis on a romantic vision of history so typical of Fascism and the dominance of 'visionary politics' as a response to a Realpolitik presentation of history (White 1987: 72-75).

A scientific study in the field of history on Nazi German cultural propaganda in Finland between 1933 and 1940 has been published by Britta Hiedanniemi. The roles of key figures from cultural life and the world of art who cooperated with Germany have been charted in monographs. Detailed research on cultural exchange has been complicated by the fairly tho- rough destruction of official German documented sources in the final phase of the war. The documents that are available are mainly contemporary printed sources such as newspaper and magazine articles and printed exhibition catalogues, plus diaries and memoirs and a very small amount of correspondence from private archives (Hiedanniemi 1980; Wuorimaa 1967; Levanto 1991; Kruskopf 1998).

At the international level, research on the influence of National Socialism on the art world in Finland is a theme of topical importance. In the last few years, such national research has been carried out in several countries as part of an international project. For example, the Geschichte der Kunstgeschichte im Nationalsozialismus joint project carried out by German universities and research institutions has documented sources and collated the information studied into a single database (www.welib.de/ gkns/index.htm). The Swedish Sveriges förhàllande till nazismen, Nazityskland och förintelsen project is a broad undertaking made up of smaller research projects (www.historia.su.se/ swenaz/publ/ Nazismen.pdf).

\section{BUILDING LINKS WITH THE NORTH}

The terms 'national' and 'racial' were key concepts that were used as rhetorical instruments in the National Socialist theory of history. In relations with Scandinavia, one of the key terms was 'Nordic'. In Nazi race theory, the 'Nordic' race, as defined by race theoretician Hans F.K. Günther in his writing on the Nordic concept in 1925, was ranked the highest. The party's principal ideologist, Alfred Rosenberg (1893-1945), developed and reshaped the definition of the Nordic race in his ideological best-seller Der Mythus des 20. Jahrhunderts (The Myth of the Twentieth Centu- 
ry, 1930). The book mixed together mythical and racial elements of history with theories of art. The mystification of Nordic and Germanic race and blood had a key role in this.

Rosenberg adopted the term nordisch ("Nordic'), derived from Günther's racial theory, as part of his own cultural and political programme, which was given the name 'The Nordic concept' in line with its model. Unlike Günther, Rosenberg included the Finnish-speaking 'East Baltic' portion of the Finnish population in the Nordic race; Günther had only included the Swedish-speaking population of Finland. Rosenberg considered the Finns' task as guardians of the eastern corner of the new Europe a very important one and took the view that the opposition to Communism demonstrated in the Finns' struggle for independence in 1918 supported the acceptance of the Finns as one of the leading nations on the European mainland. In Nazi ideology, the term 'Nordic' thus became separated from its racialist roots to become characterized as a political and indeterminate ideological qualifying concept. Thus also the Nordic concept programme, as managed by different users, developed into a complex tangle in which two other distinct strands could be distinguished, in addition to the Rosenberg core.

The party's foreign policy agency, Aussenpolitisches Amt der NSDAP, set up a special department to handle relations with the Nordic countries in 1934, with Thilo von Trotha, Alfred Rosenberg's private secretary, as its head. The cultural history trend was specifically personified by von Trotha and his interpretation of the Nordic concept, and many other ingredients were mixed in with the race theories of Günther, including nineteenth-century Nordic Romanticism, which in its day had explored links between Germanic and ancient Scand- inavian culture. The third trend in the Nordic concept covered the fairly practical operating concept of the National Socialist Nordische Gesellschaft of Lübeck. This association ran its own business operations and managed a network of businesses which traded in the Nordic countries. The association also took an active part in Nordic cultural work with the Baltic countries and organized a total of 200 separate events in Baltic coastal towns, including the annual Nordische Tage event in Lübeck, which was launched in 1934 (PA, Letter from Dr. Timm to the AA 7.5.1934; Wuorimaa 1967: 59-60; Hiedanniemi 1980: 27, 36-37; 60-63).

The German National Socialists invested substantial resources into fostering Scandinavian relations. Alfred Rosenberg became the key figure, and his influence extended to all sub-areas of Nordic cooperation. Among other things, he was in the leadership of the Nordische Gesellschaft, the regionally organized party association focusing on Scandinavian relations.

Alfred Rosenberg was an avowed anti-Semite who felt a deep repugnance not only to Judaism but also to the Christian Church. Indeed, he became the spiritual leader of the $\mathrm{Na}$ tional Socialist neo-pagan movement. His dream of the future was to distil symbols from Nordic tales and legends to replace the Old Testament symbols of the Judaeo-Christian religion. This National Socialist religion was to have cherished the tales of Odin, linking them with ancient legends and the teachings of Meister Eckehart, and also with a wide range of Germanic cultural tradition up to the time of Walter von der Vogelweide. Rosenberg believed that these ingredients would later metamorphose into religious symbols. Rosenberg's writings aroused considerable opposition from the Church and in cultural circles. 
Rosenberg wrote a pamphlet to counter Christian opposition. Indeed, a good deal was written about the National Socialists' relationship with the Church, in the Finnish press as elsewhere. Sentencing Evangelical priests to jail or concentration camp received substantial news coverage (Rosenberg 1936: 614; Rosenberg 1935; Denzler \& Fabricius 1993).

There was considerable competition for influence amongst the Nazi élite. Propaganda Minister Josef Goebbels and Alfred Rosenberg represented opposing views on art and were heated opponents in many disputes on other matters, too. Goebbels' influence grew as the Nazi cultural administration expanded, and he gained control of the Reichskulturkammer. Correspondingly, Rosenberg's influence declined by 1935 as the organization he headed, Kampfbund für Deutsche Kultur, lost its significance as the field of political action changed. Once the National Socialists had achieved a dominant position, the operating practices used in the combative stage were no longer required. (Brenner 1963: 78-86; Lane 1985: 176177; Petropoulos 1996: 34). The eclectic ideological aspects espoused by Rosenberg were sidelined in party policy: the public reasons given for this were political arguments veiled in rationalism, though privately and unofficially Rosenberg's mystical writings were laughed at and considered to be a hotchpotch of humbug. Hitler's and Rosenberg's views on the importance of race to ideology differed from each other. Rosenberg was keen to develop racial doctrine into a mystic cult, whereas Hitler declared that Nazi racial doctrine was a matter of tending and guiding the moral stature of a people defined by blood. Hitler did not warm to the notion of Scandinavia as the racial homeland of the purest Germanic people. He turned his gaze to the south, as his own ideals were above all shaped by Classical Antiquity (Bollmus 1989: 226-227; Demandt 2002: 282283, 291, 297).

\section{EXHIBITIONS AS INSTRUMENTS OF NAZI PRO-} PAGANDA

Confused in its basic concept and split up into several different schools of thought, the 'Nordic concept' programme soon plunged into a political crisis. In the Nordic countries, overt Nazi propaganda was met with repugnance. Effectively, the only instrument left to the Germans was cultural exchange, subtly infused with elements of propaganda. Official art exhibitions in Finland and Germany were organized as harmonious demonstrations of cultural cooperation.

A major exhibition of Finnish art was organized in Germany in 1935, showing 220 pictures and 50 pieces of sculpture. The main organizer of the exhibition was the Finnish government, with the Nordische Gesellschaft and the N.S. Kulturgemeinde as partners in charge of the practical organization. The patrons of the exhibition were Reichsleiter Alfred Rosenberg for the Germans and the Finnish Ambassador in Berlin, Aarne Wuorimaa, for the Finns. Both countries appointed an honorary committee of the great and good for the exhibition. The group that actually did the work in Finland included representatives of the Ministry for Foreign Affairs and the art world and a representative from the Ateneum Art Museum. The commissioner for the exhibition was Dr. Bertel Hintze, who held the post of Chief Curator at the Helsinki Kunsthalle. The text in the exhibition catalogue was written by Edvard Richter, secretary to the National Art Committee (Exhibition catalogue 1935; Hiedanniemi 1980: 92-94). 


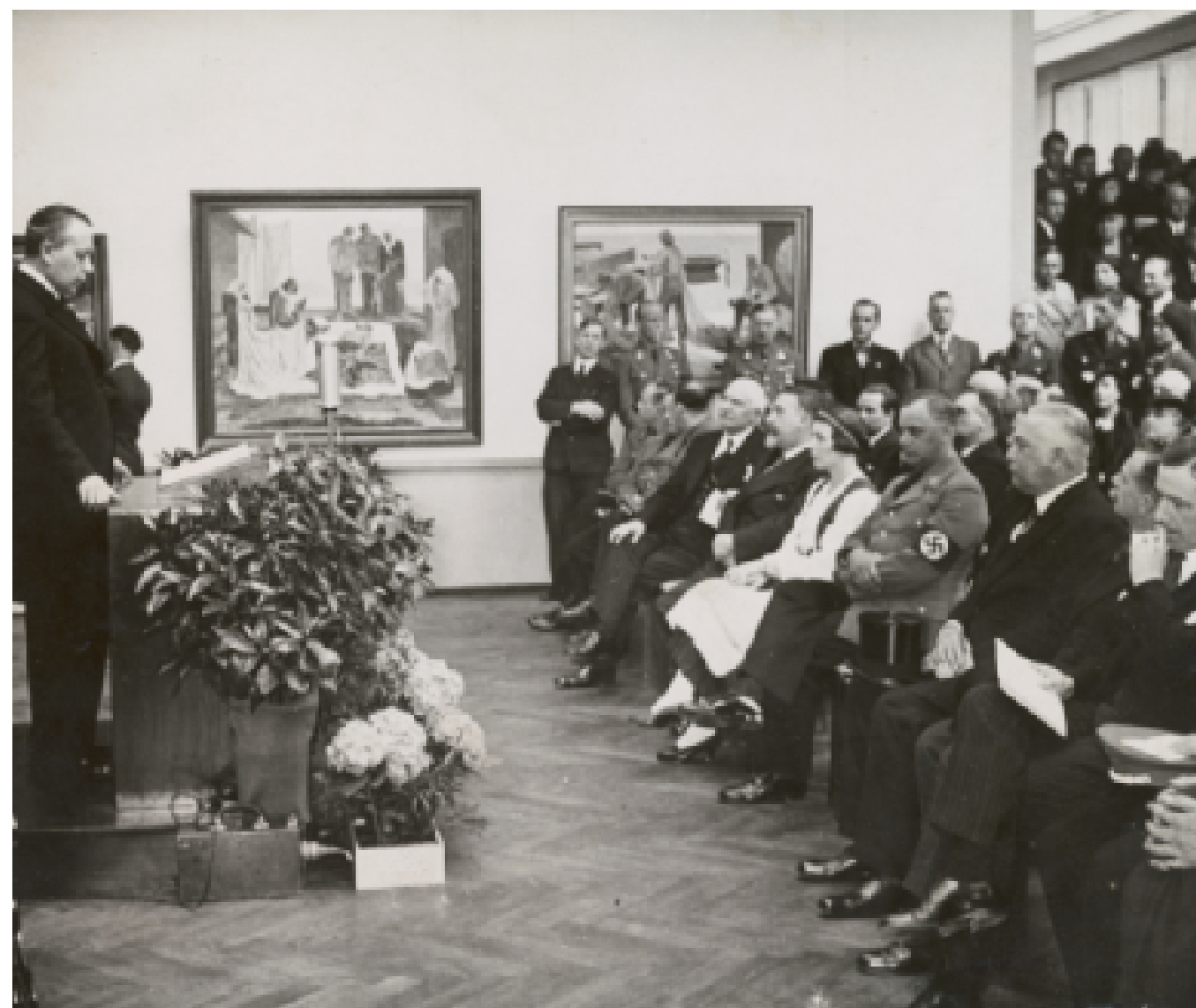

Fig. 1. The gala opening of the exhibition of Finnish art in Berlin in May 1935. Aarne Wuorimad, the Finnish ambassador, is speaking, and Reichsleiter Alfred Rosenberg can be seen in uniform in the front row. Photo: Central Art Archives, Finnish National Gallery.

The exhibition opened at the N.S. Kulturgemeinde gallery on Tiergartenstrasse in Berlin on May 11, 1935. From Berlin, the exhibition went on to Düsseldorf and Hamburg in its entirety. Altogether, 16 German cities expressed an interest in hosting the exhibition.

Besides the opening celebrations, the party organizations arranged a series of other events. Reichsleiter Rosenberg hosted a breakfast at the Aussenpolitisches Amt. The event brought together all the front-line politicians and cultural bodies involved in propaganda. In response, the Finnish ambassador gave a tea party at the Finnish embassy. Those present included diplomats from the Czech, Lithuanian and Latvian embassies and staff from the German Foreign Ministry and the party's foreign affairs agency. 
A corresponding exhibition of German art was organized in Finland in 1936, with some 400 works by 64 artists on display at the Helsinki Kunsthalle. A lecture associated with the exhibition was given by the German professor of art history Alfred Stange (1894-1968), illustrating National Socialist ideas about art. Stange, who had been appointed to his post at the University of Bonn the previous year, had carried out a thorough political overhaul of his department in accordance with National Socialist ideology. He was also instrumental in bringing about a wider process of change in the realm of science throughout the Third Reich. Stange's department carried out studies in the geography of art with the aim of demonstrating "the German heritage" in French art. Stange was in close contact with Alfred Rosenberg. During the war, the art department at the University of Bonn was involved in campaigns to photograph French art and architecture in occupied France. It was at Stange' $s$ initiative that a research centre for art history was set up in Paris. At this centre, German National Socialist art historians wrote scientific evaluations and conveyed information exploited in the seizure of works of art and items of cultural heritage (www.welib.de/ gkns/tkg-bonn.html).

At the exhibition of German art in Helsinki, a good deal of attention was paid to looking after official relations between the two countries. German officials were represented on the honorary committee by Konstantin Freiherr von Neurath, Reich Minister for Foreign Affairs; Dr. Wilhelm Frick, Reich Minister of the Interior; and Bernhard Rust, Reich Minister for Science, Education and Culture. The political élite, on the other hand, was represented by Hermann Göring, Minister President of Prussia and Commander in
Chief of the Air Force, and Reichsleiter Alfred

Rosenberg. The Finnish side was represented by the Finnish Ambassador in Berlin, Minister Aarne Wuorimaa.

In projects such as these exhibitions, it was the party cultural organizations that did the actual work. In both the Finnish exhibition in Berlin and the German exhibition in Helsin$\mathrm{ki}$, the same two party organizations - the Nordische Gesellschaft and the N.S. Kulturgemeinde (particularly the department of visual art) - were in charge of the arrangements. Conflicts of interest had arisen between the two organizations, and in fact funding had been obtained from other German sources too, to cover the escalating exhibition costs (Hiedanniemi 1980: 92-94).

The exhibition of Finnish art only visited Berlin, Düsseldorf and Hamburg, even though many cities besides these three would have been happy to host it. In order to cater to this demand, the Lübeck head office of the Nordische Gesellschaft turned its attention to Finnish graphic art. A successful exhibition of Finnish graphic art had been held in Prague and Bratislava in 1935, and the Nordische Gesellschaf was interested in bringing this exhibition to Germany, since the organization had a comprehensive network of branch offices throughout the country and the resources to make the practical arrangements. The graphic artists agreed to the request, and the aim was to open the exhibition in Lübeck in conjunction with a national meeting of the Nordische Gesellschaft. The organization planned to invite the chancellor of the Third Reich, Adolf Hitler, and the President of the Finnish Republic, P.E. Svinhufvud, to be patrons of the exhibition (STG, letters from Dr. Timm to Lennart Segerstråhle 21.5.1935, 1.6.1935; CCA, STY II, file 1, exhibition catalogue; 


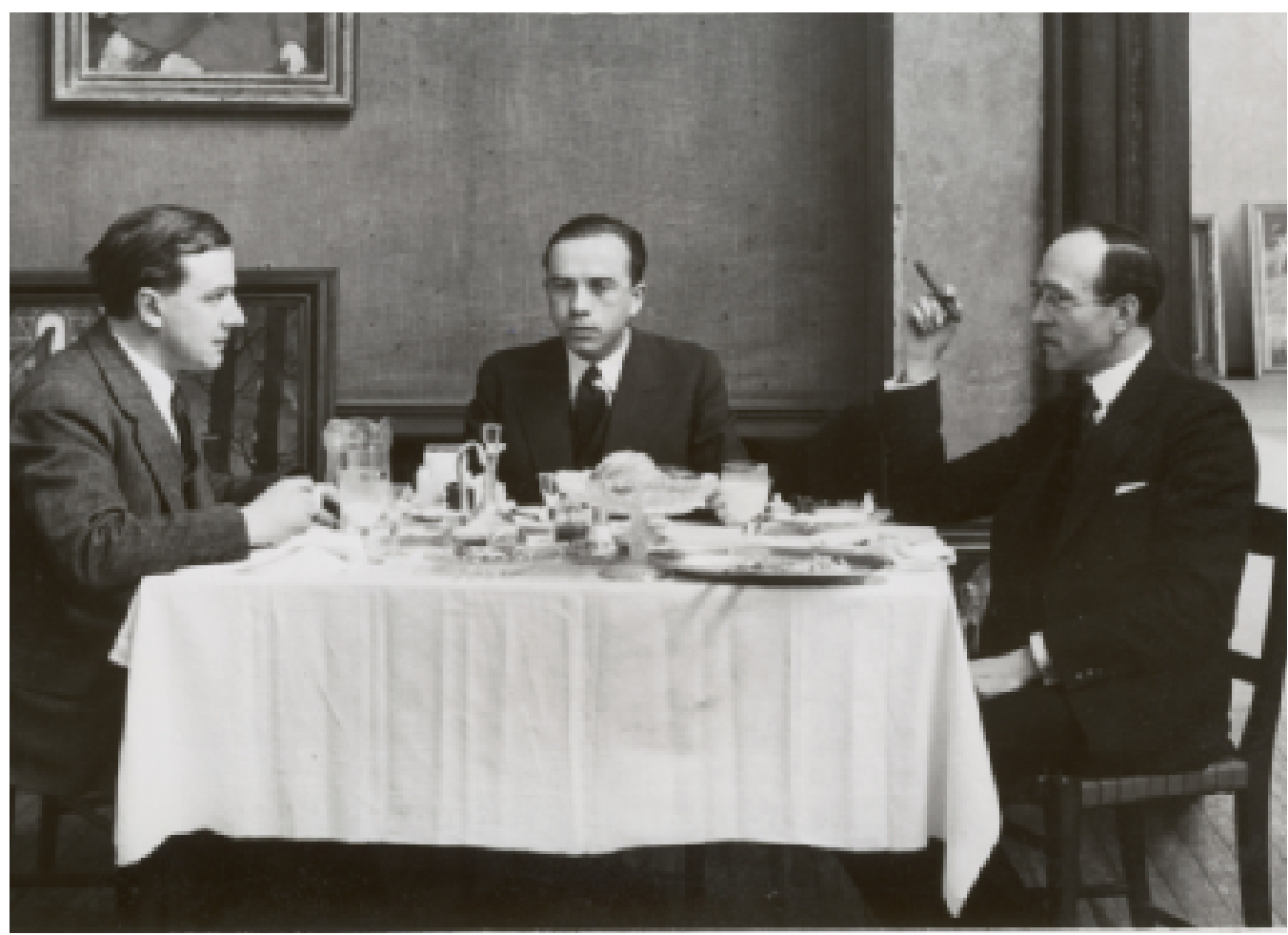

Fig. 2. The exhibition of German art was hung in the Helsinki Kunsthalle in March 1936. Bertel Hintze is here having lunch with the Germans Alexander Funkenberg and Günther Thaer.

CCA, ABH, file 13, letter from NG Reichskontor Lübeck to Bertel Hintze 20.12.1935).

\section{Germanic IMAges}

There was a good deal of coverage of the exhibition of Finnish art in Germany and the exhibition of German art in Finland in both the Finnish and German press. When reading the German newspaper articles, the contemporary political restrictions on public speech should be borne in mind. Goebbels, the propaganda minister, had brought the German media under his control. He expressed his opposi- tion to art reviews in a variety of contexts, and this led to a ban on the publication of art criticism towards the end of 1936. Criticism "after the fact", and assessments that projected art expertise, were forbidden. The National Socialist party felt that its worldview offered a comprehensive ideology which allowed the evaluation of works of art in the context of an overall concept of culture. Instead of reviews written by critics, newspapers published explanatory and descriptive texts written by 'art editors' (Kunstschriftleiter). These writers were not allowed to hide behind pseudonyms; their whole names had to be published. Art editors 
had to be well informed about the field of art they were writing about and at least thirty years old (Wulf 1963: 126-131; Brenner 1963: 108).

Newspaper articles provide a more extensive source for investigating how Finnish and German art was actualised. To today's reader, these exhibition reports and criticisms seem naïve and appear to be dictated by the political situation. However, the newspaper articles reveal the kind of network of consciousness, narrative and openly expressed goals in which national art was actualised.

The commentary on the Finnish exhibition as a whole highlighted the visionary power of Akseli Gallen-Kallela as an interpreter of the Kalevala epic. Appreciation of folk poetry was ranked high in the National Socialist conception of art. Thus the links between GallenKallela's works and the Finnish narrative tradition and the imagery of the Kalevala were highly praised. The artist was extolled as a mystic from the Finnish forests and an interpreter of Finnish tales. The fighting spirit of the heroic figures described in the epic was admired, and similarities were identified between its characters and those of the ancient Germanic tradition. The monumental style of Gallen-Kallela's frescoes and his sizable major works was admired, as too were the clear surface compositions and dramatic lines of his symbolist paintings.

German influences on the work of Finnish artists who had studied in Germany - such as Fanny Churberg, who had studied in Düsseldorf, - were emphasised. Individual artists highlighted included the painter Sulho Sipilä, both for his career as captain of a battleship and for the almost mystical nature of his matter-of-fact style (Thaer 1935a: 402-403; Thaer 1935b; Scholz 1935).
The art historian Waldemar Hartmann, who was editor of the culture section of $V \ddot{o} l-$ kischer Beobachter, the main mouthpiece of the National Socialist party, had written for the catalogue of the One Hundred Years of German Art exhibition held in Helsinki. The preface outlines national contacts in trade and culture. The Finnish war of independence and the political Nordic concept programme were highlighted as factors that cemented friendly relations. Hartmann makes a case for the political idiom of the exhibition, reflecting the German national tradition in general and its appearance in German Romanticism in particular. Nationally, the focus is on portraiture and landscape painting. National Socialist art history emphasised the realisation of national values in art. Relinquishing foreign models and alien themes was considered a good thing: the world of Antique myth had been supplanted by German landscapes and images of national life (Hartmann 1936, 6-7).

At the Helsinki exhibition, the German organizers gave particular attention to a newcomer who was ideologically suited to the National Socialists. Wilhelm Petersen (born 1900), a fairly young painter from northern Germany, submitted 23 paintings to the exhibition. His work consisted of seascapes and coastal subjects and mythological themes. Because of his Nordic racial and spiritual heritage, he was expected to become a national-epic painter, and his independence from all foreign influences was considered an asset. Petersen had had an exhibition at home in Germany in 1936, attracting a good deal of attention in the German press. He was generally seen to embody the 'Nordic concept', and on the orders of Alfred Rosenberg methodical efforts were undertaken to hail him as the greatest artist in the Third Reich. 
54 Finnish reviews of the exhibition took note of phenomena in the National Socialist concept of art. Besides cautious criticism and diplomatically veiled phrases, there were also sympathetic views of National Socialist arts policy. Ludwig Wennevirta, art critic for the extreme right-wing paper Ajan Suunta, explained the basis for the National Socialist concept of art described by the German guest lecturer Professor Alfred Stange in a separate article before the actual commentary on the exhibition, in which he gave special attention to the new German painting. Wennervirta named Wilhelm Petersen as the chief exponent of this, and in his summary he confesses his admiration for the National Socialist worldview (Wennervirta 1936).
In the independent cultural magazine $\mathrm{Fo}$ rum, V. Arti (a pseudonym for Kaarlo Väinö Valve) took the view that the Germans were miles ahead of the Finns in terms of both technique and cultural ideas. He considered their artistic outlook to be powerful, direct, free from sentimentalism, honest and aware of nature. According to Arti, German art was not overburdened with refinement in comparison with Romanesque art, particularly Italian. The reviewer considered this to be a unifying factor between Finnish and German art. Arti was ready to put German art forward as a paradigm for the future (Arti 1936).

That the National Socialist conception of art prioritized the emotional projection of the viewer, "the human proximity of art and its et-

Fig. 3. Wilhelm Petersen: Thor and the Midgard Serpent. Paavolainen 1936, page 107.

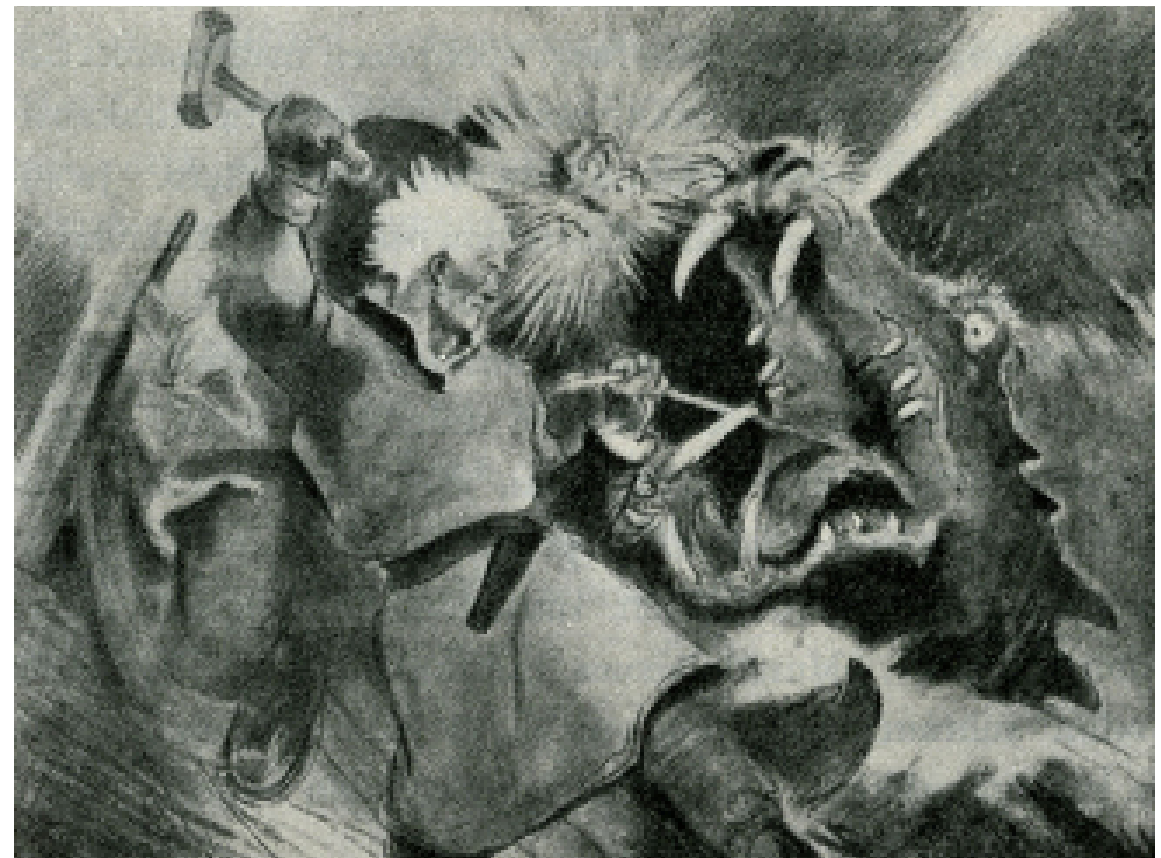


hical values", over artistic value bemused critics accustomed to the conventional evaluation approach in art history. Stiff criticism was avoided, however, and reviews were couched in cautious turns of phrase - or, as one of the most influential characters in the Finnish art world of the 1930s, professor of art history, cultural-political persona and art critic Onni Okkonen (1886-1962) put it, they focussed on technique. Okkonen's general assessment of the official art of the Third Reich was cautious in the extreme although he considered contemporary German graphic art to be of a technically high standard (Okkonen 1936a; Okkonen 1936b).

In the exhibitions organized in GermanFinnish cooperation in 1935 and 1936, National Socialist propaganda exploited the 'Nordic concept' as the ideological basis of the foreign policy programme. The Finnish writer and critic Olavi Paavolainen reported on his experiences in Germany in spring 1936 in his book Kolmannen Valtakunnan vieraana (A Guest of the Third Reich). He saw the 'Nordic concept' as a sort of immense flight from reality into the world of illusion. One of his contemporaries had defined it as 'Gothic romance'. Similarly, in Sweden the 'Nordic concept' was rejected right from the start "with icy disdain for this expedient myth." (Paavolainen 1936: 93, 98).

Nazi cultural propaganda aimed at the Nordic countries failed to achieve the desired result. The volume of criticism increased, and the Germans had to admit that the 'Nordic concept' had foundered. In 1937, Rudolf Holsti, the Finnish Minister for Foreign Affairs, began building a more neutral public image for Finnish foreign policy, which led to a cooling in relations with Germany.

By 1938, after the propaganda programme had failed, National Socialist cultural propaganda aimed at other countries was changed. The Nordische Gesellschaft magazine Der Norden stopped employing overt Nazi propagan$\mathrm{da}$ after noting the criticism it had attracted in the Nordic countries.

No sooner had the political concept come to a dead end than Nordic mythology as a subject for the visual arts began to wear out. Subsequently, the focus of National Socialist art shifted to sculpture.

National Socialist admiration for sculpture could be seen in foreign relations, too. German desires for a presentation of Finnish sculpture were repeated in various contexts. Sculpture was already prominently featured at the Finnish exhibition in Berlin in spring 1935. Wäinö Aaltonen's statue of the runner Paavo Nurmi had been installed in the exhibition gallery courtyard, and more of Aaltonen's major works were on show inside. One of these was even bought by Alfred Rosenberg himself. Correspondingly, a bronze statue of a seated girl by Fritz Klimsch was purchased for the Ateneum collection at the exhibition at the Helsinki Kunsthalle (Catalogue nr. 138, $50 \mathrm{~cm}$, inv. B I 416). German interest in Finnish sculpture can also be seen in cultural exchanges: Dr. Bertel Hintze was invited to lecture on contemporary Finnish sculpture in Germany in 1942 (CCA, ABH, file 13, letters from NG Reichskontor Lübeck to Bertel Hintze 30.5.1942, 5.8.1942).

Contemporary sculpture was also at the forefront of the German exhibition in Helsinki in 1936. Fritz Klimsch, Thorak and Richard Scheibe had established themselves in the field of monumental sculpture. In heroic imagery, a fighting spirit and an athletic body were much admired. They portrayed Wehrhaftigkeit, a valiant and militant bearing, and 
56 Wehrgedanke, a warlike disposition, while proclaiming the superiority of the Aryan race and its ability to reach great heights of sporting achievement. Depictions of the nude female body in German art had earlier been fairly rare but became more common with the advent of Nazi ideas about art (Hartmann 1936: 6-7; Paavolainen 1936: 118-122).

In terms of cultural history, the 1930s were a golden age for organized cultural policy and political art. The National Socialist 'Nordic concept' programme, which flourished for a period of four years from 1934 to 1938 , is a distinct example of a cultural propaganda project. It was a phenomenon connected with the mainstream of 1920s National Socialist racial theory and cultural policy, which both proclaimed the threat of spiritual decay in culture and of racial contamination. Fostering the priority of the Nordic race was proposed as a way of saving the situation, and art was harnessed as an instrument for carrying out this work. The Nazis spoke heatedly about the general crisis in art and culture as one of the symptoms of a larger crisis in society as a whole. The basis for Nazi theories about art consisted of classification into different categories and a sort of artistic triage to determine which art is acceptable and which should be condemned (Auslese). Abstract and modern art was condemned as degenerate, since its typically deformed shapes were identified with the physically handicapped and the fantasies of the mentally diseased (Brenner 1963: 36-39, 108116; Petropoulos 1996: 31-33).

\section{BIBLIOGRAPHY AND SOURCES}

\author{
Abbreviations \\ $\mathrm{AA}=$ Auswertiges Amt \\ $\mathrm{AHB}=$ Archive of Bertel Hintze \\ $\mathrm{CCA}=$ Central Art Archives \\ $\mathrm{PA}=$ Politisches Archiv des Auswärtigen Amtes \\ STG $=$ Suomen Taidegraafikot ry: arkisto (Archive of \\ the Association of Finnish Printmakers), Jyväskylä, \\ Finland \\ STY $=$ Suomen Taideyhdistyksen arkisto
}

\section{Archival materials}

Politisches Archiv des Auswärtigen Amtes Berlin, Germany (PA)

Kult, Institute und Vereingungen: Nordische Gesellschaft R 65.814

Suomen Taidegraafikot ry: arkisto (Archive of the Association of Finnish Printmakers), Jyväskylä, Finland

Archive of Lennart Segerstråhle: Correspondence

Finnish national Gallery, Central Art Archive, Helsinki, Finland (CCA)

Archive of Bertel Hintze (ABH) Correspondence: File 13 NG Reichskontor Lübeck Suomen Taideyhdistyksen arkisto (Archive of the Finnish Art Society), (STY) Part II, File 1

\section{BIBLIOGRAPHY}

Arti, V [=Valve, Kaarlo Väinö]: "Saksan taiteen näyttely Taidehallissa". Forum 1936/4.

Barbian, Jan-Pieter: "Kulturwerte im Zeitkampf. Die Kulturabkommen des "Dritten Reiches" als Instrumente nationalsoziatistischer Aussenpolitik". Archiv für Kulturgeschichte 1992/2, 415-459.

Bollmus, Reinhard: "Alfred Rosenberg - Chefideologe des Nationalsozialismus?” Die braune Elite I. Wissenschaftliche Buchgesellschaft: Darmstadt 1989.

Brenner, Hildegard: Die Kunstpolitik des Nationalsozi- 
alismus. Rowolt: München 1963.

Demandt, Alexander: "Klassik als Klischee. Hitler und Antike." Historische Zeitschrift Band 274 (2002), 281-313.

Denzler, Georg \& Fabricius, Volker: Christen und Nationalsozialisten. Frankfurt a.M. 1993.

Exhibition catalogue 1935: Nationale Finnische Kunstausstellung in Deutschland veranstaltet von der Finnischen Regierung in Gemeinschaft mit der Nordische Gesellschaft und der NS.-Kulturgemeinde (1935).

Hartmann, Waldemar: "Saksan taiteen näyttely Suomessa 1936". Sata vuotta Saksan ta idetta. Tysk konst under 100 ar 7.3.-29.3.1936. Taidehalli. Konsthallen, 1936.

Hiedanniemi, Britta: Kulttuuriin verhottua politiikkaa. Kansallissosialistisen Saksan kulttuuripropaganda Suomessa 1933-1940. Otava: Helsinki1980.

Kruskopf, Erik: En konstens världsman.Bertel Hintze 1901-1969. Svenska litteratursällskapet i Finland: Helsingfors 1998.

Lane, Barbara Miller: Architecture and politics in Germany 1918-1945. Harvard University Press: Cambridge 1985.

Levanto, Yrjänä: Kirjoitetut kuvat. Ludvig Wennervirran taidekäsitys. Helsinki 1991.

Okkonen, Onni: "Saksan taiteen näyttely I." Uusi Suomi 8.3.1936.

Okkonen, Onni: "Saksan taiteen näyttely II." Uusi Suomi 21.3.1936.

Paavolainen, Olavi: Kolmannen valtakunnan vieraana. Gummerus, Jyväskyla 1936.

Petropoulos, Jonathan: Art as Politics in the Third Reich. University of the North Carolina Press, USA 1996.

Rosenberg, Alfred: An die Dunkelmänner unserer Zeit eine Antwort auf die Angriffe gegen den "Mythus des 20. Jahrhunderts". 22. Auflage . Hoheneichen-Verlag, München 1935.

Rosenberg Alfred: Der Mythus des 20. Jahrhunderts
95.-98. Auflage. Hoheneichen-Verlag: München 1936.

Scholz, Robert: "Ein Gang durch die Finnische Kunstausstellung." Völkischer Beobachter 14.5.1935.

Thaer, Günther (1935a): "Finnische Kunst geht ihren Weg. Gedanken zur Berliner Kunstaustellung." Nationalsozilistische Monatshefte 1935, Heft 62/ Mai 1935.

Thaer, Günther (1935b): "Finnische Kunst als Kulturbild." Deutsche Allgem. Zeitung 10.5.1935.

Wennervirta, Ludvig: "Sata vuotta Saksan taidetta." Ajan Suunta 1.4.1936.

White, Hayden: The Content of the Form. Narrative Discourse and Historical Representation. The John Hopkins University Press, Baltimore and London 1987.

Wulf, Joseph: Die bildenden Künste im Dritten Reich. Eine Dokumentation. Sigbert Mohn: Gütersloh 1963.

Wuorimaa, Aarne: Lähettiläänä Hitlerin Saksassa. Otava: Helsinki 1967.

\section{Material published in internet}

Geschichte der Kunstgeschichte im Nationalsozialimus: Sveriges förhållande till nazismen, Nazityskland och Förintelsen. www.historia.su.se/swenaz/publ/Nazismen.pdf.

*Hanna Pirinen

Senior assistant, Ph.D., Docent in Art History

Address: University of Jyväskylä

Department of Art and Culture Studies

P.O Box 35 (JT)

FIN-40014 Jvyäskylän yliopisto

Hapirine@campus.jyu.fi 